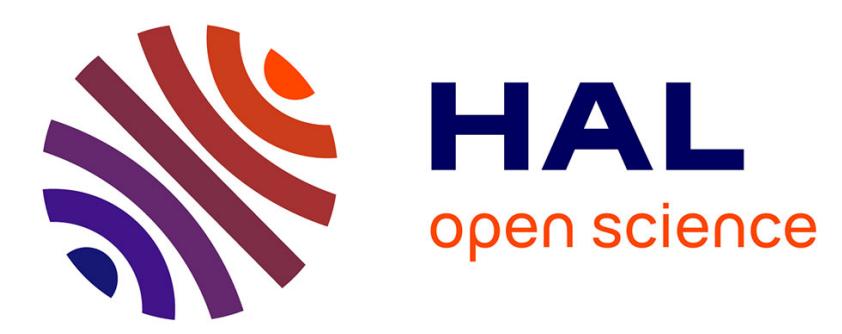

\title{
Achieving Flexibility through Insecurity: A Comparison of Work Environments in Fixed-term and Permanent Jobs in Finland and Canada
}

Antti Saloniemi, Isik Urla Zeytinoglu

\section{- To cite this version:}

Antti Saloniemi, Isik Urla Zeytinoglu. Achieving Flexibility through Insecurity: A Comparison of Work Environments in Fixed-term and Permanent Jobs in Finland and Canada. European Journal of Industrial Relations, 2007, 13 (1), pp.109-128. 10.1177/0959680107073971 . hal-00570959

\section{HAL Id: hal-00570959 \\ https://hal.science/hal-00570959}

Submitted on 1 Mar 2011

HAL is a multi-disciplinary open access archive for the deposit and dissemination of scientific research documents, whether they are published or not. The documents may come from teaching and research institutions in France or abroad, or from public or private research centers.
L'archive ouverte pluridisciplinaire HAL, est destinée au dépôt et à la diffusion de documents scientifiques de niveau recherche, publiés ou non, émanant des établissements d'enseignement et de recherche français ou étrangers, des laboratoires publics ou privés. 


\title{
Antti Saloniemi and Isik Urla Zeytinoglu
}

University of Tampere, FINLAND and McMaster University, CANADA

\section{Achieving Flexibility through Insecurity: A Comparison of Work Environments in Fixed-term and Permanent Jobs in Finland and Canada}

\begin{abstract}
In this comparative study of Finland and Canada, we use representative data to examine work environments in fixed-term and permanent jobs. Results are similar for all workers regardless of whether they are employed on fixed-term or permanent contracts. All workers feel their working hours are inflexible, but feel they have control over the tasks they perform and they have low risk of accident. The only difference is in the feelings of job insecurity: fixed-term workers, in both Finland and Canada, feel more insecure than those in permanent jobs. Our findings indicate that the global trends in flexibility and insecurity permeate all workers. KEYWORDS: Canada - Finland - fixed-term jobs - flexibility - insecurity - permanent jobs
\end{abstract}

\section{Introduction}

Over the last two decades, the labour markets in Canada and Finland as well as in most other industrialized countries have been experiencing major transformations. Countries are seeing the employment scene change from relatively secure full-time employment dominated by the manufacturing sector to a more flexible, insecure labour market where new entrants are mostly on part-time or fixed-term contracts in service or information technology sectors. By fixed-term jobs we refer to employment on an interim basis with a predetermined employment termination date.

Intergovernmental organizations are promoting working time flexibility, labour cost flexibility and employment flexibility (Casey, 2004; OECD, 2003a). Fixed-term employment has now become a permanent fixture in labour markets in most industrialized countries (Auer and Cazes, 2003). In Finland, 18 percent of paid workers are on fixed-term contracts (Lehto and Sutela, 1999), and 13 percent in Canada (Galarneau, 2005). 
While there seem to be good intentions in promoting fixed-term jobs for those who have difficulty entering the labour market, concerns are raised about the quality of these jobs (Gonäs, 2003; ILO, 2003; Maxwell and Saunders, 2003). There is accumulated literature showing that those in fixed-term jobs in Canada and in other Anglo-Saxon countries experience poor working conditions compared to those in permanent jobs. Conversely, Nordic studies from Finland and Sweden, for example, show more positive working conditions for workers in fixed-term jobs (Saloniemi et al., 2002, 2004; Sverke et al., 2000). However, for these workers the duration of temporary employment is relatively high. In Finland, the median duration of fixed-term employment before moving into permanent employment is more than three years (Kauhanen, 2002); in Canada, the median duration is two years (Kapsalis and Tourigny, 2004).

Despite the accumulating evidence on fixed-term employment and its established share in the labour market, the literature on how fixed-term workers feel about their jobs is sparse. In this article, we examine fixedterm workers' perceptions of flexibility and insecurity in their work environments. We also compare their views to those of employees in permanent jobs. We focus on two OECD member countries, Finland and Canada. In the field of international and comparative industrial relations, published research has rarely focused primarily on either country. The general view has been that knowledge of the USA would be sufficient to understand the Canadian industrial relations environment, and likewise a study of Sweden would suffice for understanding Finnish industrial relations. Both assumptions are questionable, and in this study we attempt partially to close the gap in knowledge of these two countries.

We test the hypothesis that workers in fixed-term jobs will perceive high levels of job insecurity, time inflexibility, low control over work and high accident risk as compared to workers in permanent jobs. We discuss our findings in a comparative perspective of similarities and differences in fixed-term employment in Finland and Canada, and link the findings to global trends in labour flexibility and insecurity and to the promotion of short-term employment for flexibility in labour markets by governments and some intergovernmental organizations.

\section{The Conceptualization of Labour Flexibility and Job Insecurity}

Our study adopts the broad conceptualization of labour flexibility and job insecurity proposed by Standing (1997). In this conceptualization, the employer achieves flexibility by imposing a number of insecurities on workers. We take a broad view of flexibility and use employment (numerical) flexibility as the overarching form of flexibility. We focus on working 
time flexibility, work task flexibility, and the flexibility of shifting risks onto workers. While there can be flexibility approaches that are mutually beneficial to both employees and employers, generally speaking flexibility for employers tends to create inflexibility and job insecurity for workers.

In this study we focus on how workers feel about their employment security. Working time flexibility is worker empowering where workers have the freedom to decide on the starting and ending time of their workday. Work task flexibility is likewise empowering if workers have control over how to perform the tasks involved in their jobs: the lowest measure of workers' control over their work. Lastly, we focus on whether increased flexibility is shifting risks onto workers. We examine this through workers' perceived accident risk in the work environment, but it can also be examined as an outcome of working-time flexibility, work-task flexibility, and the general flexibility of shifting risks onto workers.

Globally, research shows that job security and the protection built around traditional employment relationships are being challenged by new forms of work including fixed-term contracts (ILO, 2003). Comparing two Anglo-Saxon countries - Britain and Australia - de Ruyter and Burgess (2003) show growing labour insecurity in both countries in the 1990s despite employment growth. In other industrialized countries throughout the 1990s, workers increasingly felt insecure in their jobs (Auer and Cazes, 2003). While an argument can be made that those in fixed-term jobs have more freedom to negotiate variations in their work obligations because of the flexible nature of their jobs, many workers on fixed-term contracts do not in fact have such luxury to pick and choose their hours of work and how to perform their tasks. They work in jobs with time inflexibility and low control over work. Workers in fixed-term jobs are often not given sufficient training and orientation to their work environments, and thus they are more prone to accidents and injury. Thus, we hypothesize that workers in fixed-term jobs will perceive job insecurity, time inflexibility, low control over work, and high accident risk in comparison to workers with permanent contracts.

\section{Background on the Labour Market Regimes in Finland and Canada as Related to Fixed-term Jobs}

Research on Finland and Canada shows that despite some affinities to the Anglo-Saxon model in Canada and the Nordic model in Finland, in each country there are many unique features of the industrial relations environment and many distinctive solutions to labour market problems. More importantly, as we will show below, the employment conditions of workers in fixed-term jobs are similar in both countries. In this background section, we discuss the economic systems and labour 
markets, legal and collective agreement protections, unionization rates, and the ethnic/racial/immigrant composition for both Finland and Canada.

\section{Background on Finland}

In terms of geopolitical location, Finland is on the periphery of the economic power and market scope of the EU. With a population of just over five million it is one of the smallest member states, and until the collapse of the Soviet Union its economy was strongly oriented to the Russian market, which still remains important. It became a member of the EU in 1995, and is the only Nordic country to have adopted the single currency.

In terms of its economic and labour market regimes, Finland was a latecomer in the development of a centralized industrial relations system and an extensive welfare state in comparison to other Scandinavian countries. Presently Finland seems to be departing from the 'traditional' Nordic model towards a hybrid one combining some Nordic features with neoliberal approaches (Aho and Lehtonen, 2002; Kettunen, 2001). The recession of the early 1990s caused a permanent restructuring of labour markets. During its deepest phase, the unemployment rate reached nearly 20 percent; since then it has declined but is still above the EU average. One result of this employment crisis is a decline in permanent employment; employers in both public and private have become less willing to create permanent jobs.

All workers in Finland, whether on permanent or fixed-term employment contracts, have good legal protection. In the application of the law, however, there may be discrepancies between the two groups of workers; but we know of no studies that show the application and effectiveness of labour laws for fixed-term workers in the Finnish labour market.

On the other hand, the regulation of the labour market through collective bargaining plays a more important role than the legislation. Collective bargaining coverage is high ( 90 percent), and the agreements apply to fixedterm as well as permanent workers. Still, this has not guaranteed equality between workers in fixed-term and permanent jobs: those working on a fixed-term basis tend to have lower wages as well as lower unemployment insurance. They also receive lower retirement benefits and holiday entitlements. A substantial proportion of workers in fixed-term jobs have to resort to social assistance (Kauhanen, 2002).

The unionization rate is high in Finland, not only for workers in permanent jobs but also for those on fixed-term contracts. Reported percentages differ depending on how union membership statistics are measured. However, nearly 80 percent of workers were members of trade unions 
in the late 1990s (Lehto and Sutela, 1999), and in 1997 the unionization rate among workers in fixed-term jobs was 74 percent (Ahtiainen, 2003).

Finland has historically been a country of emigration, and today it does not have an active immigration policy. Though there are some foreign workers and refugees, the number of foreign workers in the labour force is very small (1.8 percent), the lowest proportion in the EU. The largest group of foreign workers comes from the former Soviet Union, particularly Estonia. The next largest groups are from Sweden and the UK. Lastly there are some foreign workers from Africa. These workers are the most marginalized of Finland's foreign workers, not only because of their small numbers but also in terms of their status in the labour market. They work in the least desirable jobs and face the highest rate of unemployment. For example, although the unemployment rate is high among foreign workers ( 24 percent), the rate is nearly double among those who have emigrated from Africa (OECD, 2003b).

\section{Background on Canada}

Canada's close proximity to the USA and the sheer power of the US economy have always affected the Canadian economy and its labour policy. Since the USA is Canada's largest trading partner and many companies in Canada are subsidiaries of US multinationals, there is an inevitable effect on Canada's employment regime. The increasingly flexible US labour market of the last three decades has led to changes in Canada, making its labour market also more flexible for employers and insecure for workers. Permanent full-time employment declined in the last two decades and has been replaced by a variety of flexible, non-standard, fixed-term employment forms. Currently, the percentage of workers in permanent full-time jobs is below the 1989 levels (Vosko et al., 2003).

Employment regulation involves a mixture of the French legislative approach and Anglo-Saxon laissez faire. In comparison to the USA, Canadian workers enjoy a favourable social policy environment with universal health care coverage and relatively good (un)employment insurance coverage: Canada is considered 'the welfare country of North America'. In terms of legislated benefits for workers, a broad legal governance regime covers employment standards, health and safety, and labour laws at both provincial and federal levels. Though only about 10 percent of the working population falls under federal jurisdiction, this sets the standard for provincial regimes. Thus despite some differences between federal and provincial employment and labour laws, there are many similarities.

Formally, federal and provincial laws provide the same protection to all workers regardless of employment status. However, the reality for 
workers in fixed-term jobs is that they rarely meet the conditions in terms of continuous working hours or stable relationship with an employer to be eligible for coverage under employment and labour laws. And in some cases, fixed-term workers are excluded from legal protection because they are considered self-employed, rather than dependent employees. The protection that the laws provide to fulltime permanent workers may not be better than for fixed-term workers (Chaykowski, 2005), though there is little systematic empirical evidence on the extent of compliance with existing legislation. Just over 30 percent of workers in Canada are unionized (more than double the rate in the USA), but the unionization rate is lower (20 percent) for fixed-term workers.

Canada has an active immigration policy, and thus its population is much more diverse than Finland's. Earlier immigrants to Canada came from Europe, but since the 1960s most immigration has been from countries with non-White populations and often diverse religious and cultural backgrounds. These immigrants and their Canadian-born descendants are called 'Visible Minorities'. The last census shows that 19 percent of Canadians are immigrants and 13 percent are Visible Minorities. However, about 75 percent of the immigrants who arrived in the last two decades are Visible Minorities (Bélanger et al., 2005). A racialized segregation (Zeytinoglu and Muteshi, 2000) is emerging in the Canadian labour market with Visible Minorities employed in the most marginalized forms of employment.

In terms of the ethnic/racial/immigrant composition of the labour force in fixed-term jobs, on the surface there seem to be clear differences with Finland. However, close examination of the labour market and employment prospects of the marginalized groups reveals more similarities than differences. Both countries employ their White workers in better jobs, and disproportionately more Visible Minorities work in marginalized jobs. The only difference between the two countries is the proportion of Visible Minorities or foreigners in the labour force.

\section{Data and Analysis}

Against this background, we now turn to our data and examine the perceptions of fixed-term workers as compared to those in permanent jobs. We use data from two surveys carried out by Statistics Finland and Statistics Canada. The two surveys are substantially similar in their questions, allowing us to compare the work environment for fixed-term and permanent workers in both countries. Since the two surveys were not designed to be used in comparative studies, an essential task was to check and define the congruence of the variables between the surveys. 
We first compared definitions of fixed-term versus permanent jobs in each survey, since this is the main independent variable in our analysis.

In the Finnish survey, respondents were asked is your job permanent or fixed-term?', and in the Canadian, this is phrased 'is your job permanent or not?' Prior to starting the analysis of the data, we discussed the meaning of the two questions and response options in the context of both countries' experience with non-permanent employment. We decided that for those whose jobs are not permanent the responses mean essentially the same in each survey. In both countries, respondents are saying that they do not have an employment contract which is permanent. They know that their employment contract will end at a specified date, or when the required tasks are over or the product or service is delivered. Thus we decided that the concept of 'fixed-term' applied equally in both surveys.

\section{Finnish Data: Variables and Analysis}

The Finnish data are from the Quality of Work Life survey 1997 carried out by Statistics Finland. The survey was conducted through face-to-face interviews with employees aged 15 to 64 . Out of 3895 people contacted, 2978 (79 percent) agreed to participate. Data are representative of the population in Finland (Lehto and Sutela, 1999).

Perceived job insecurity, time flexibility and control over work are traditional psychosocial dimensions of work, while accident risk is a physical work environment factor. In the survey, workers gave their perceptions of their work situation. These factors are the dependent variables in our study. The Finnish survey asked workers whether their present jobs carried a risk of temporary lay-off, dismissal or unemployment. Those who perceived one or more of these threats in their jobs were classified as workers with perceived job insecurity. Time flexibility was investigated by the question 'do you have strictly set starting and finishing times for your work, or can you personally influence them by at least 30 minutes either way?' Participants who gave the second answer were categorized as employees with time flexibility. Control over work was explored with the following question: 'are you able to influence your working methods a lot, quite a lot, little or not at all?' Employees who chose the alternatives 'a lot' or 'quite a lot' were considered to have high control over work. Lastly, for accident risk the survey asked in your work, do you experience accident risk as a distinct hazard, think about it occasionally or experience it as no hazard at all?' Participants who agreed with the first alternative were classified as those with high accident risk.

Along with these questions, we used variables describing participants' demographic and human capital characteristics, sector and unionization to control for the effects of these variables on perceived job insecurity, time inflexibility, control over work and accident risk. The demographic 
characteristics are age, gender, marital status, and having children younger than 15. Human capital characteristics are occupation, level of education, and supervision responsibilities. Occupation is used as a proxy for socioeconomic status and is separated into three groups: upper white-collar, lower white-collar and blue-collar occupations. We classified workers into five sectors: manufacturing, construction, transport, private sector services and public sector services. Unionization identifies whether the job is unionized or covered by a collective agreement.

In analysing the data we first conducted frequency distributions and then tested for differences between permanent and fixed-term workers' work environment using cross-tabulations and chi-square tests. Next, we conducted logistic regression analyses to examine the associations between fixed-term jobs and the four work environment dimensions while controlling for other factors.

\section{Canadian Data: Variables and Analysis}

Canadian data are from the General Social Survey (GSS) Cycle 9 carried out in 1994 by Statistics Canada. The survey covers 10,000 individuals aged 15 and over in all 10 provinces of Canada. The response rate was 83 percent. For this study, only those with a job are selected, constituting a sample of 6365 workers. On a weighted basis this is 13,034,502 workers. The weighted Canadian data are representative of the population. The respondents from the GSS do not form a simple random sample of the target population. Therefore the survey weights must be used in performing analysis in order to account for the over-and-under representation (GSS User's Guide, 1995). The basic sampling weight assigned to each sampled individual has been adjusted to reflect the age and sex composition of the various provincial populations as projected by the Labour Force Survey for each month of 1994. The GSS User's Guide (1995) explains the steps for using the working weight for each individual. These guidelines were used in the analysis of the Canadian data. For the perceived job insecurity variable, the survey asked whether workers thought they would lose their jobs or be laid off in the next year. Those who said very likely or somewhat likely are coded as workers with job insecurity, and those who said somewhat unlikely and very unlikely are coded as having job security. Time flexibility was investigated by asking 'do you have a flexible schedule that allows you to choose the time you begin and end your work day?' Respondents who gave a positive answer were categorized as employees with time flexibility. For control over work, respondents were asked to indicate their agreement or disagreement with the following: 'there is a lot of freedom to decide how you do your work'; those who agreed were considered to have high control over their work. For accident risk the question was 'has the risk of accident or injury in 
your work environment caused you worry or stress in the past 12 months?' Those who agreed were coded as perceiving high accident risk.

We use the same type of variables explained above for Finnish data to describe Canadian respondents' demographic and human capital characteristics, their employment sector, and whether or not the job is unionized. We follow the same type of analysis for the Canadian data. In all analyses, weighted data are used. Table 1 summarizes the demographic characteristics of respondents in both countries.

\section{Characteristics of Workers in Fixed-term Jobs in Finland and Associations with Work Environments}

Workers in fixed-term jobs comprised 18 percent of the Finnish respondents in 1997 (though the proportion had declined to 14 percent in 2003;

TABLE 1. Characteristics of Survey Respondents (\%)

\begin{tabular}{|c|c|c|}
\hline & Canada & Finland \\
\hline Fixed-term contract & 9 & 18 \\
\hline Gender: Female & 45 & 53 \\
\hline \multicolumn{3}{|l|}{ Industry: } \\
\hline Manufacturing & 16 & 24 \\
\hline Construction & 5 & 6 \\
\hline Transport & 13 & 9 \\
\hline Private services & 40 & 24 \\
\hline Public services & 27 & 37 \\
\hline \multicolumn{3}{|l|}{ Education: } \\
\hline Less than high school & 21 & 24 \\
\hline High school & 29 & 31 \\
\hline Community college & 30 & 25 \\
\hline University or higher & 20 & 20 \\
\hline \multicolumn{3}{|l|}{ Socio-economic status } \\
\hline Upper white-collar & 14 & 22 \\
\hline Lower white-collar & 46 & 40 \\
\hline Blue-collar & 40 & 38 \\
\hline Union member & 11 & 79 \\
\hline Married/cohabiting & 68 & 74 \\
\hline \multicolumn{3}{|l|}{ Age } \\
\hline$\leq 29$ & 28 & 20 \\
\hline $30-49$ & 54 & 60 \\
\hline$\geq 50$ & 18 & 20 \\
\hline Children under 15 & 35 & 41 \\
\hline Supervisory responsibilities & 31 & 32 \\
\hline Total & 6365 & 2978 \\
\hline
\end{tabular}


Sutela and Lehto, 2005). In Table 2 we focus on the characteristics of fixedterm workers. The majority are women (62 percent), and 56 percent are in public services. They are younger than permanent workers and more likely to be single and without dependent children. There are no major differences between fixed-term and permanent workers in terms of educational level or occupational status. As already indicated, fixed-term workers are

TABLE 2. Characteristics of Permanent and Fixed-term Workers in Finland (\%)

\begin{tabular}{|c|c|c|c|}
\hline & $\begin{array}{l}\text { Permanent } \\
\text { employees }\end{array}$ & $\begin{array}{l}\text { Fixed-term } \\
\text { employees }\end{array}$ & $\begin{array}{l}\text { Proportion } \\
\text { fixed-term }\end{array}$ \\
\hline \multicolumn{4}{|l|}{ Gender } \\
\hline Men & 49 & 38 & 15 \\
\hline Women & 51 & 62 & 21 \\
\hline \multicolumn{4}{|l|}{ Industry } \\
\hline Manufacturing & 26 & 13 & 10 \\
\hline Construction & 6 & 8 & 23 \\
\hline Transport & 9 & 5 & 11 \\
\hline Private services & 26 & 19 & 14 \\
\hline Public services & 33 & 56 & 27 \\
\hline \multicolumn{4}{|l|}{ Education } \\
\hline Less than high school & 24 & 20 & 16 \\
\hline High school degree & 32 & 29 & 17 \\
\hline Community college & 24 & 30 & 22 \\
\hline University degree & 20 & 21 & 18 \\
\hline \multicolumn{4}{|l|}{ Socio-economic status } \\
\hline Upper white collar & 22 & 22 & 18 \\
\hline Lower white collar & 39 & 43 & 20 \\
\hline Blue collar & 39 & 35 & 17 \\
\hline \multicolumn{4}{|l|}{ Union membership } \\
\hline Yes & 80 & 74 & 17 \\
\hline No & 20 & 26 & 23 \\
\hline \multicolumn{4}{|l|}{ Marital status } \\
\hline Married/cohabiting & 75 & 64 & 16 \\
\hline Single/divorced/widowed & 25 & 36 & 24 \\
\hline \multicolumn{4}{|l|}{ Age } \\
\hline$\leq 29$ & 15 & 42 & 38 \\
\hline $30-49$ & 63 & 49 & 15 \\
\hline$\geq 50$ & 22 & 9 & 8 \\
\hline \multicolumn{4}{|l|}{ Children under 15} \\
\hline Yes & 43 & 34 & 20 \\
\hline No & 57 & 66 & 15 \\
\hline \multicolumn{4}{|l|}{ Supervisory responsibilities } \\
\hline Yes & 34 & 22 & 13 \\
\hline No & 66 & 78 & 21 \\
\hline
\end{tabular}


almost as highly unionized as those with permanent jobs. However, they are significantly less likely to have supervisory responsibilities.

In Table 3 we analyse associations between workers' employment status and job insecurity. While only 30 percent of all respondents say that they are likely to lose their job, 64 percent of fixed-term workers expect to. The responses are significantly different between permanent and fixed-term workers. After adjusting for all the control variables, the perceived risk of losing their jobs is more than seven times higher among fixed-term workers. We further analysed this finding using logistic regression analysis and controlling for the demographic, human capital, sector and unionization characteristics. When we control for the effects of these factors, results again confirm that those in fixed-term jobs perceive higher job insecurity than permanent workers. This finding is in line with our hypothesis and gives an indication of how marginalized these workers have become in terms of job security.

None of the other work environment factors, that is, perceived time flexibility, control over work, or accident risk, showed significant differences between fixed-term and permanent workers in Finland. Close to half of all respondents said that they did not have time flexibility in deciding when to start and end their work day; the response was similar for those in fixed-term jobs. The majority of, workers, permanent and fixed-term, believed that they had control over their work tasks. Lastly, only a small minority of all workers and of those in fixed-term jobs perceived a significant accident risk in their work environment.

We conducted further analyses on these issues using logistic regression analyses controlling for the effects of demographic, human capital, sector and unionization characteristics. Results again showed no significant effects of fixed-term or permanent employment on working time flexibility, control over work tasks, and accident risk. Thus contrary to our hypothesis, for these work environment outcome factors, those on fixedterm contracts did not perceive their work environment to be worse than those in permanent jobs. On the contrary, both groups of workers had similar perceptions in terms of time flexibility, work autonomy, and accident risks. Because of space limitations we do not present the detailed tables. They are, however, available from the authors.

\section{Characteristics of Workers in Fixed-term Jobs in Canada and Associations with Work Environments}

Workers in fixed-term jobs make up nine percent of the respondents in the Canadian data (see Table 1). This percentage is similar to the proportions in studies using other data sets (Galarneau, 2005). There is a regular (continuous) part-time worker group consisting of 11 percent of the work force. 


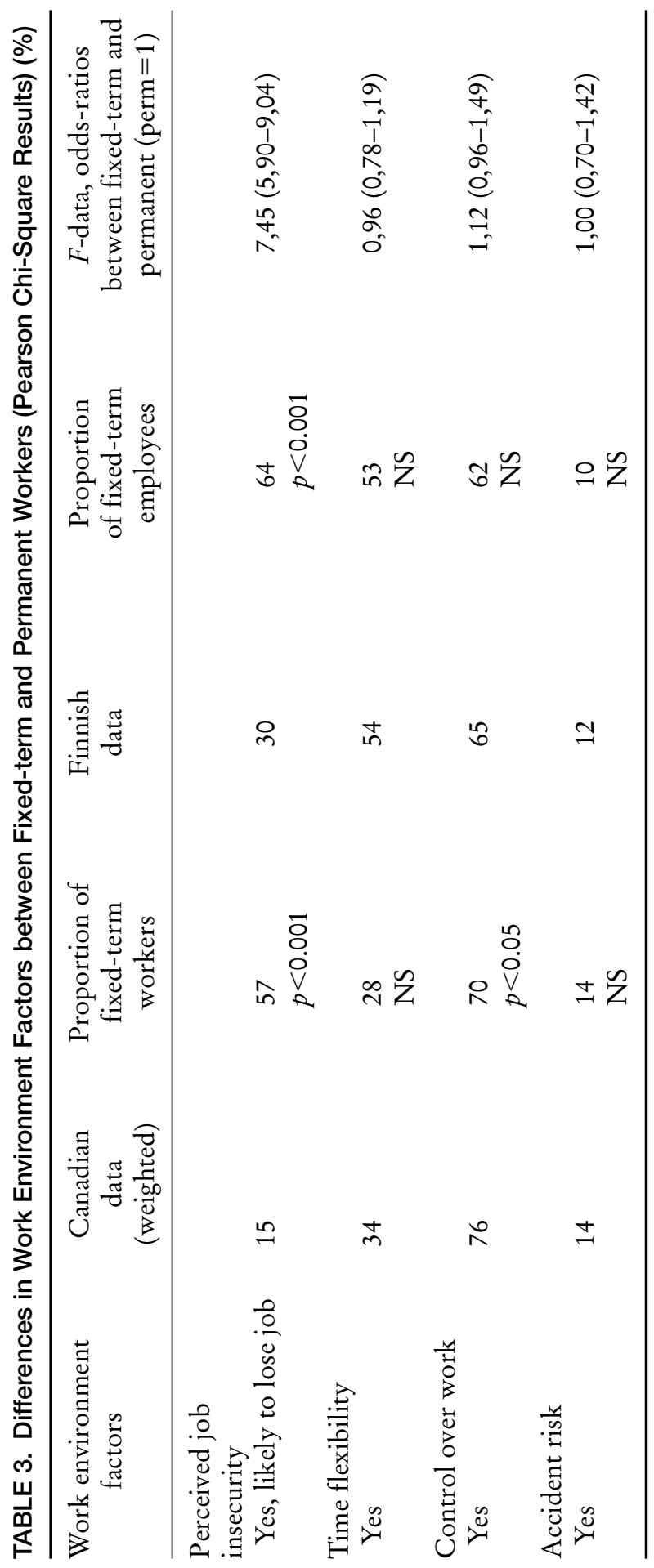


These workers provide continuity in service to employers while proving them with flexibility in scheduling. The survey respondents in Canada are similar to Finland in terms of demographic characteristics of age, gender, marital status and dependent children. In terms of human capital characteristics, about a fifth of Canadians are in the lowest and highest education levels respectively, and about a third have supervisory responsibilities. The majority of workers are in lower-white collar and blue-collar occupations. Most workers are in the services sector.

The General Social Survey (GSS) is designed to capture the Canadian population and the weights are assigned to represent the population, not the labour force. Thus, 11 percent reporting union membership is lower than the known union membership rate. Still we use these data because this is the only Canadian survey that incorporates questions on workers' perceptions of their work environments.

Fixed-term employment accounted for almost one-fifth of the overall growth in paid employment between 1997 and 2003 (Galarneau, 2005). The proportion of the labour force with fixed-term jobs was 11 percent in 1997 and 13 percent in 2003. Contract workers are the largest group of fixed-term workers, constituting five percent of the paid workforce in 1997 and six percent in 2003. Among contract workers, women (57 percent) and those with higher education (community college or university degree) ( 80 percent) make up the majority. Seasonal and casual workers within the fixed-term employment category each make up about three percent in 1997 and 2003. Agency workers comprise only 0.2 percent of paid workers in each year.

Turning to our dataset, as we show in Table 3, focusing on all respondents and using the weighted data, only 15 percent of Canadian workers perceive their job as insecure. However, among those in fixed-term jobs, 57 percent perceive job insecurity, and the difference is statistically significant. The logistic regression analysis, controlling for demographic, human capital, sector and unionization characteristics, confirms the significant difference between workers in fixed-term versus permanent jobs. This finding supports our hypothesis that those in fixed-term jobs will feel higher job insecurity than those in permanent jobs.

In terms of perceived time flexibility, as we show in Table 3, the majority of the workers in permanent jobs and on fixed-term contracts in Canada say that there is no time flexibility in their jobs and they cannot adjust the starting and ending hours of their work day. In particular, 66 percent of all workers and 72 percent of those in fixed-term jobs say that there is time inflexibility in their jobs. Logistic regressions confirm that there is no difference between fixed-term and permanent workers in terms of time flexibility. Thus, contrary to our hypothesis, those in fixed-term jobs as well as those in permanent jobs in Canada feel time inflexibility in their jobs. 
Examining workers' perceived control over how they do their work, the majority of Canadian workers believe that they have such control (76 percent). Among those on fixed-term contracts this figure is 70 percent. The statistical analysis shows a weak significant difference between those in fixed-term and permanent jobs (see Table 3). However, when we conduct further analysis, using logistic regression and controlling for demographic, human capital, sector and unionization characteristics, results show no significant difference between workers in fixed-term and permanent jobs. In other words, when we control for many other factors, Canadian workers with permanent or fixed-term jobs feel similarly about the amount of control they have over how they perform their work tasks.

Canadian workers feel overwhelmingly positive about the accident or injury risk in their jobs. In terms of perceived accident risk, 86 percent of all workers in Canada do not perceive such a risk in their work environment, and among fixed-term contract workers, 86 percent do not perceive such a risk (see Table 3). The logistic regression analysis shows no significant difference between workers with fixed-term or permanent jobs. Thus, contrary to our hypothesis, fixed-term workers do not perceive any more risks than those with permanent jobs.

\section{Discussions and Conclusions}

In this comparative analysis of fixed-term and permanent employment, we examined work environments in Finland and Canada. We applied Standing's (1997) flexibility and job insecurity conceptualizations to workers' experiences and focused on four dimensions of the work environment: perceived job insecurity, time inflexibility, low control over work and high accident risk. We expected to find generally poorer work environments for workers in fixed-term jobs in comparison to workers in permanent jobs. However, what we found was that although in both countries a higher percentage of fixed-term workers were concerned that they were likely to lose their jobs, none of the other work environment factors showed significant differences between workers with fixed-term or permanent jobs. This was contrary to general expectations and our hypothesis.

Our results, however, are an indication of how work environments have become similar for all workers regardless of the employment contracts they have. Both those in permanent jobs and in fixed-term jobs similarly feel the negative aspects of flexibility, that is, job insecurity and time inflexibility, and, on the positive side, they similarly feel in control of how to perform the tasks of their jobs and believe that their work environments are free of accidents or injuries. 
In addition to the analysis of workers with fixed-term versus permanent jobs, our study offered a comparative analysis of working life in Finland and Canada. More Finnish workers believed that they were likely to lose their jobs than those in Canada, and a large majority of workers in Canada and close to half of the workers in Finland felt time inflexibility in their jobs. On the other hand, Canadian employees felt they have more control over their work than their counterparts in Finland. In the perceptions of accident risks, the results were essentially the same in both countries with most workers feeling their jobs were accident or injury free. When we analysed both the Finnish and Canadian data controlling for many factors that can affect work environment, we found that workers in both countries have very similar work experiences. By and large, in terms of workers' perceptions of their work environment, our results stress more similarities than differences between Finland and Canada.

Although our results accurately represent the perceptions of the respondents, there are some limitations of the data that do not permit us to conduct a more comprehensive analysis of the hypothesized work environment differences. First, different types of employment within the fixed-term job category are not captured in our study. In the Finnish survey, there are categories which distinguish different types of contract within fixed-term employment, but the numbers are too small for such an analysis. In the Canadian survey there are no comparable questions to examine similar issues. We recommend further research to focus specifically on the experiences of workers in different types of jobs within fixed-term employment to capture their perceptions of flexibility and insecurity in their work environments.

Second, while surveys provide data on a large number of workers allowing for generalizations for the population, they hardly reach the most marginalized jobs, that is, those that are so casual in terms of the number of hours worked in a single workplace that they are often not included in the surveys. Recent discussions stress that problems in fixedterm employment tend to concentrate in these marginalized employment forms. In Finland, we know that there are workers from Russia and Estonia employed on construction sites as illegal labour, but there are no studies capturing their experiences to give us a better understanding of the work environments in these marginalized jobs. In Canada, there are many casual part-time workers in marginalized jobs, but they are difficult to capture in large datasets. They have insecure jobs, time inflexibility, no control over how to perform the tasks of their jobs, and, as an extension of these factors, many have no control over their lives. They cannot make plans for their personal lives because they do not know whether they will be employed next week or the hours of their employment if they do obtain work. They earn very low wages and have no benefits. They cannot even get a bank loan to improve their lives such as buying a house or 
a car as banks do not give credit to people who have casual jobs. They are unable to change their working conditions for fear of losing their hardfound jobs. They are not given training on workplace hazards and are prone to accidents and injuries. We suggest that further studies should focus on workers in these most marginalized jobs to provide evidence on their working conditions.

We should also stress that we used only a few questions, limited in scope, in examining workers' perceptions of their work environments. These questions accurately captured workers' perceptions, but they concentrated on the immediate work and work environment. Questions dealing with incomes, future employment prospects, incremental effects of these working conditions on the emotional health of workers and their families, and the connections between personal and work lives as other possible indicators of perceived flexibility and job insecurity were not captured in these surveys. We recommend further studies to examine these issues.

In conclusion, our study showed that the work environments are very similar in Canada and Finland and for most workers in each country regardless of working in fixed-term or permanent jobs. This finding, we argue, should be analysed in the light of the global phenomenon of employers' goals of achieving labour flexibility at the expense of workers' security. As Léonard (2001) has shown, the socio-political environment in Europe in the 1990s allowed negotiators at company level to conclude agreements with enhanced flexibility and adaptability in workplaces. Most of the flexibilities were achieved through permanent, full-time workers since they also started to increasingly feel insecurity in their jobs (see, for example for Italy, Baldassarini et al., 2004; and for France, Setti and Brosnan, 2004). Similarly, in Finland (Lavikka, 2004) and in Canada the restructured work environments are enhancing employers' flexibility while deteriorating job security for most workers. An increasing number of workers in Canada are now 'vulnerable' regardless of whether they have permanent or fixed-term contracts. And in Finland the improvements in the economy in the late 1990s did not bring back the traditional job security (Lehto and Sutela, 2005). The trend towards fixed-term employment, particularly for newcomers to the labour market, is now established as regular practice although savings achieved are hard to show (Kauhanen, 2002).

Our results are in line with studies pointing to the complex nature of work environments and the dynamics between working conditions and type of job. There are broader trends in labour flexibility and growing insecurity for most workers in all types of jobs (Dickens, 2003). There is an erosion of working conditions across many countries and the 'peripheralization' or 'casualization' of 'core' employment alongside a growing number of fixed-term, non-standard workers. Such developments are 
blurring the boundaries between the internal and external labour markets (Grimshaw and Rubery, 1998). Not only are work relationships changing, organizational forms are also changing and reshaping the employment contract. Fixed-term employment is becoming a form of self-employment with each worker left on his/her own to find continuous work in the labour market (Marchington et al., 2005). The important point here is that these workers are in the labour market on a continuous basis, but their jobs are fixed-term, and they have consistently to be seeking new jobs in order to have continued employment income. In some cases, fixed-term jobs are being disguised as permanent employment in outsourced companies. The companies themselves are precarious and function like a fixed-term job market, where the company survival is based on shortterm contracts (as the example of the home care sector in Ontario, Canada shows).

As Hyman (2003) argues, the widespread and increasing sense of insecurity among workers is reflecting the risks that have pervaded the contemporary capitalist society. It is frequently the least powerful workers who are forced to take these risks. We argue that in the long-term, negative effects of these jobs on individual workers, their employers and the society will outweigh the short-term benefits. Certainly some companies that have outsourced jobs, even to offshore companies, are starting to see the importance of those jobs in supporting their core activities and are starting to 'insource'. Many of these jobs must be converted to better quality permanent jobs if companies are expected to be efficient and profitable. Otherwise, low quality jobs will bring low quality service and products, making customers or clients increasingly dissatisfied and ultimately resulting in low, if any, profits.

As Wilkinson and Lapido (2002) suggest, while achieving flexibility, employers can also aim to improve the working lives of the workers. This needs to be supported by statutory protection or protective social policy (Zeytinoglu and Muteshi, 2000). Laws in most countries, however, are not aligned with the new work environment and workers in a variety of peripheral jobs tend to fall outside legal protection. Most workers, regardless of working in fixed-term or permanent contracts, are now feeling insecure. Relaxed labour protection has given employers the unilateral power to dictate to workers the conditions of work, and workers, being powerless, are accepting those employment conditions through force majeure.

We concur with Hyman (2003) that the widespread and growing sense of insecurity among workers reflects the increasing extent to which risks of all kinds have pervaded the contemporary capitalist society. There are choices to be made at the societal level. The choice has to be between creating huge inequalities in our society for the profit motives of the capitalist economy, or in providing fulfilling work and personal life, decent standards of work and earnings to all workers, and 
distributing the profits equitably among those who contributed to their creation. We recommend choosing the latter in order for society, not only in Finland and Canada but also globally, to progress and prosper.

\section{REFERENCES}

Aho, S. and Lehtonen, H. (2002) 'The State of Welfare State Anno 1992 and Five Years Later: Finland', in J. Pacolet (ed.) The State of Welfare State in Europe Anno 1992 and Beyond, pp. 131-58. Toronto: APF Press.

Ahtiainen, L. (2003) Palkansaajien järjestäytyminen Suomessa 2001. [With an English summary: Wage and Salary Earners' Organization in Finland in 2001.] Helsinki: Työministeriö.

Auer, P. and Cazes, S. (eds) (2003) Employment Stability in the Age of Flexibility: Evidence From Industrialized Countries. Geneva: ILO.

Baldassarini, A., Casagrande, C., Lucarelli, A., Mattonelli, L. and Tibaldi, M. (2004) 'An Attempt of Measuring Hours Worked in the General Government Sector: Some Provisional Results in the National Accounts Framework', Proceedings of the Flexibility in Working Time and the BreakUp of Social Time, Paris, February.

Bélanger, A., Caron Malenfant, E., Martel, L., Carriere, Y., Hicks, C. and Rowe, G. (2005) Population Projections of Visible Minority Groups Canada, Provinces and Regions, 2001-2017. Statistics Canada, Demography Division. Ottawa: Industry Canada.

Casey, B.H. (2004) 'The OECD Jobs Strategy and the European Employment Strategy: Two Views of the Labour Market and the Welfare State', European Journal of Industrial Relations 10(3): 329-52.

Chaykowski, R. (2005) Non-standard Work and Economic Vulnerability. Canadian Policy Research Networks, Document No. 3, Vulnerable Workers Series, available online at [http://www.cprn.org/].

de Ruyter, A. and Burgess, J. (2003) 'Growing Labour Insecurity in Australia and the UK in the Midst of Job Growth: Beware the Anglo-Saxon Model', European Journal of Industrial Relations 9(2): 223-44.

Dickens, L. (2003) 'Changing Contours of the Employment Relationship and New Modes of Labour Regulation', Report by Rapporteur, IIRA World Congress. Berlin, September.

Galarneau, D. (2005) 'Earning of Temporary versus Permanent Employees', Perspectives on Labour and Income (Statistics Canada-Catalogue no. 75-001-XIE) 6(1): 5-17.

Gonäs, L. (2003) 'Gender Segmentation and the European Employment Strategy: Levels and Divisions', IIRA Congress, Berlin.

Grimshaw, D. and Rubery, J. (1998) 'Integrating the Internal and External Labour Markets', Cambridge Journal of Economics 22: 199-220.

GSS User's Guide (1995) The 1994 General Social Survey Cycle 9 - Education, Work and Retirement, Public Use Microdata File Documentation and User's Guide (Statistics Canada).

Hyman, R. (2003) 'Editorial', European Journal of Industrial Relations 9(2): 139-40. 
ILO (2003) The Scope of the Employment Relationship, International Labour Conference, Report V. Geneva: ILO.

Kapsalis, C. and Tourigny, P. (2004) 'Duration of Non-standard Employment', Perspectives on Labour and Income (Statistics Canada, 75-001-XPE) 5(12): 5-13.

Kauhanen, M. (2002) Mä̈räaikaiset työsubteet ja toimeentulon riskit. [With an English Summary: Financial Security in Fixed-term Employment Contracts.] Helsinki: Kela, Sosiaali- ja terveysturvan tutkimuksia 69.

Kettunen, P. (2001) 'The Nordic Welfare State in Finland', Scandinavian Journal of History 26(3): 225-47.

Lavikka, R. (2004) 'Fulfilment or Slavery? The Changing Sense of Self at Work', in T. Heiskanen and J. Hearn (eds) Information Society and Workplace. Spaces, Boundaries and Agency, pp. 143-77. London: Routledge.

Lehto, A.M. and Sutela, H. (1999) Gender Equality in Working Life. Helsinki: Statistics Finland.

Lehto, A.M. and Sutela, H. (2005) Threats and Opportunities. Findings of Finnish Quality of Working Life Surveys 1977-2003. Helsinki: Statistics Finland.

Léonard, E. (2001) 'Industrial Relations and the Regulation of Employment in Europe', European Journal of Industrial Relations 7(1): 27-47.

Marchington, M., Grimshaw, D., Rubery, J. and Willmott, H. (eds) (2005) Fragmenting Work: Blurring Organizational Boundaries and Disordering Hierarchies. Oxford: Oxford University Press.

Maxwell, J. and Saunders, R. (2003) 'Changing Labour Markets: Key Challenges Facing Canada', paper prepared for Human Resources Development Canada, Canadian Policy Research Networks, available online at: [www.cprn.org].

OECD (2003a) Employment Outlook 2003. Paris: OECD.

OECD (2003b) Trends in International Migration. Continuous Reporting System on Migration. Annual Report. Paris: OECD.

Saloniemi, A., Virtanen, P. and Koivisto, A.M. (2002) 'Fixed-term Employment and Psychosocial Work Environment: Experiences in the Finnish Working Life', in I.U. Zeytinoglu (ed.) Flexible Work Arrangements: Conceptualizations and International Experiences, pp. 181-202. The Hague: Kluwer.

Saloniemi, A., Virtanen, P. and Vahtera, J. (2004) 'The Work Environment in Fixed-term Jobs: Are Poor Psychosocial Conditions Inevitable?', Work, Employment and Society 18(1): 193-208.

Setti, N. and Brosnan, P. (2004) 'The First Aubrey Law: The Experiences of 10 French Enterprises', Proceedings of the Flexibility in Working Time and the Break-Up of Social Time, International Symposium on Working Time, Paris, February.

Standing, G. (1997) 'Globalization, Labour Flexibility and Insecurity: The Era of Market Regulation', European Journal of Industrial Relations 3(1): 7-37.

Sverke, M., Gallagher, D. and Hellgren, J. (2000) 'Job Stress, Well-being, and Work Attitudes Among Employees with Different Employment Contracts', in K. Isaksson, C. Hogstedt, C. Eriksson and T. Theorell (eds) Health Effects of the New Labour Market, pp. 145-67. New York: Kluwer. 
Vallée, G. (2005) Towards Enhancing the Employment Conditions of Vulnerable Workers: A Public Policy Perspective. Canadian Policy Research Networks, Document No. 2, Vulnerable Workers Series, available online at: [http://www.cprn.org/].

Vosko, L.F., Zukewich, N. and Cranford, C. (2003) 'Beyond Non-standard Work: A New Typology of Employment', Perspectives on Labour and Income (Statistics Canada, Catalogue no. 75-001-XIE) 4(10): 16-24. Wilkinson, F. and Lapido, D. (2002) 'What Can Governments Do?', in B. Burchell, D. Ladipo and F. Wilkinson (eds) Job Insecurity and Work Intensification, pp. 172-84. London: Routledge.

Zeytinoglu, I.U. and Muteshi, J. (2000) 'Gender, Race and Class Dimensions of Non-standard Work', Relations industrielles/Industrial Relations 55(1): 133-67.

\author{
ANTTI SALONIEMI is Professor of Sociology at University of Tampere, \\ Finland. \\ ADDRESS: University of Tampere, PO Box 181, 28101 Pori, Finland. [e-mail: \\ antti.saloniemi@uta.fi]
}

ISIK URLA ZEYTINOGLU is Professor in the DeGroote School of Business, McMaster University, Canada. [e-mail: zeytino@mcmaster.ca] 